\title{
In situ detection of sequence-specific DNA binding activity specified by a recombinant bacteriophage
}

\author{
Charles R. Vinson, Karen L. LaMarco, Peter F. Johnson, William H. Landschulz, and Steven L. \\ McKnight
}

Department of Embryology, Carnegie Institution of Washington, Baltimore, Maryland 21210 USA

\begin{abstract}
We have used a recombinant bacteriophage that expresses the DNA-binding domain of C/EBP to optimize conditions for a screening technique that may facilitate the cloning of genes that encode sequence-specific DNA-binding proteins. The method relies on the expression of cDNA inserts in bacteriophage $\lambda$ gt11 . Fusion protein adsorbed onto nitrocellulose filters is probed with radioactive, double-stranded DNA as a ligand. Two procedures greatly increase the level of binding between ligand and recombinant fusion protein. First, nitrocellulose filters are processed through a denaturation/renaturation regimen using $6 \mathrm{~m}$ guanidine hydrochloride. Second, synthetic DNA corresponding to the specific binding site is catenated extensively using DNA ligase. The combination of these procedures leads to remarkably strong detection signals. Specific DNAbinding signals can be detected on duplicate filters, and filters can be washed and reused by repeating the cycle of denaturation/renaturation.
\end{abstract}

[Key Words: DNA-binding proteins; $\lambda$ gt 11 ; molecular cloning; C/EBP; catenated DNA probes; denaturation/ renaturation]

Received April 13, 1988; revised version accepted May 25, 1988.

Sequence-specific DNA-binding proteins can be detected in vitro by a variety of procedures, including nitrocellulose filter binding (Linn and Riggs 1975), DNase I footprinting (Galas and Schmitz 1978), and electrophoretic mobility retardation (Fried and Crothers 1981; Garner and Revzin 1981). These methods of detection have been used as assays to track the biochemical purification of regulatory proteins that bind DNA in a sequence-specific manner (Briggs et al. 1986; Chodosh et al. 1986; Rosenfeld and Kelly 1986; Fletcher et al. 1987; Johnson et al. 1987; Lee et al. 1987; Mitchell et al. 1987; O'Neill and Kelly 1987; Prywes and Roeder 1987; Sturm et al. 1987; Treisman 1987; Wu et al. 1987). Although regulatory proteins that bind to specific DNA sequence can be isolated from eukaryotic cells in pure form, their rarity precludes retrieval of quantities sufficient for biophysical studies such as spectroscopy or crystallography. To circumvent this problem, it will be necessary to overproduce regulatory proteins using recombinant DNA clones of their encoding DNA.

The conventional route that has allowed cloning of cDNAs that encode sequence-specific DNA-binding proteins is arduous at best. The protein of interest is purified by biochemical fractionation and used to generate either a specific antiserum or partial amino acid sequence. In either case, the minimal amount of purified protein, ranging perhaps between 100 pmole and 1 $\mu$ mole, requires massive amounts of starting material. Our own experiences with the protein that we term C/EBP are outlined by Landschulz et al. 1988 (this issue). Starting with 200 rat livers, which allowed isolation of roughly $10^{11}$ nuclei, we purified $\sim 3 \mu \mathrm{g}$ of a $14-\mathrm{kD}$ fragment of C/EBP ( $\sim 200$ pmole). This amount of protein was sufficient for the determination of a partial amino acid sequence which, in turn, allowed synthesis of a peptide and subsequent generation of an anti-peptide antibody. Finally, by using the antibody reagent to screen a bacteriophage $\lambda g t 11$ library, we were able to isolate a cDNA copy of the C/EBP mRNA.

Some of the more tedious aspects of the aforementioned cloning route can be side-stepped, in certain cases, by direct screening of a $\lambda g t 11$ library using a specific DNA sequence as a ligand. This technique, first accomplished by Singh et al. (1988), represents a logical extension of $\lambda$ gtll screening. We have used our $\lambda$ gtll recombinant that specifies the synthesis of C/EBP as a test system to examine variables in the DNA ligand screening procedure. This paper outlines two procedures that greatly enhance the in situ binding of bacterially synthesized C/EBP to its cognate DNA.

\section{Results}

Previous efforts from our laboratory have led to the isolation of a recombinant bacteriophage, termed L20, that contains the DNA-binding domain of an enhancer binding protein $(\mathrm{C} / \mathrm{EBP})$ fused in frame to the $\beta$-galactosidase gene of bacteriophage $\lambda g t 11$ (Landschulz et al. 1988). Using this recombinant clone, we determined experimental conditions that allowed its identification, with radioactive DNA as a ligand. An equal mix of L20 and its parental bacteriophage, $\lambda g t 11$, was used to infect 
a permissive strain of Escherichia coli. Proteins from bacteriophage plaques were adsorbed onto nitrocellulose filters according to published procedures (Young and Davis 1983).

Initial binding assays were carried out using two DNA probes. One probe consisted of a synthetic, doublestranded DNA molecule that was known to constitute an avid binding site for C/EBP (Landschulz et al. 1988). This DNA molecule, initially constituting a synthetic, 20-bp duplex, was ligated to form a mixed head-to-head and head-to-tail catenate, with a mean length of $\sim 200$ bp. The other probe was sonicated salmon sperm DNA, bearing a mean length of $\sim 400 \mathrm{bp}$. Both DNA probes were labeled by nick-translation (Maniatis et al. 1982) and introduced into binding reactions with nitrocellulose filters (Materials and methods). After a 2-hr binding reaction at $4^{\circ} \mathrm{C}$, filters were washed briefly and exposed to X-ray film overnight. As shown in Figure 1, neither probe bound to any significant degree to protein deposited on the filter by either the L20 bacteriophage or its $\lambda$ gt11 parent.

Each filter was then subjected to a denaturation/renaturation cycle, using $6 \mathrm{~m}$ guanidine hydrochloride. After graded removal of the denaturant, filters were returned to binding buffer and probed a second time with both DNA samples. These conditions led to a significant in-

Figure 1. In situ binding of synthetic C/EBP DNA substrate to $\beta$-galactosidase fusion protein synthesized by bacteriophage L20. A permissive strain of $E$. coli was infected with an equal mix of bacteriophage $\lambda$ strain gt 11 and the recombinant derivative that contains a cDNA copy of the C/EBP mRNA (designated L20; Landschulz et al. 1988). Infected cells were mixed with X-gal, IPTG, and top agar, spread onto two 100-mm petri plates, and incubated at $42^{\circ} \mathrm{C}$ for $4 \mathrm{hr}$. Color photographs of the two plates, shown at the top of each column, distinguish plaques corresponding to $\lambda \mathrm{gt} l \mathrm{l}$ (blue) from those corresponding to the L20 recombinant (clear). Each of the plates was overlayed with an IPTG-impregnated nitrocellulose filter and incubated at $37^{\circ} \mathrm{C}$ for an additional $6 \mathrm{hr}$. Filters were removed, air-dried, and incubated either with radiolabeled DNA bearing a high concentration of C/EBP-binding sites or with radiolabeled salmon sperm DNA. After being washed, the filters were exposed to $\mathrm{X}$-ray film overnight, generating the autoradiographic images shown in $1 A$ /C/EBP DNA probe) and $2 A$ /salmon sperm DNA probe). After autoradiography, the filters were cycled through a denaturation/renaturation procedure, using $6 \mathrm{M}$ guanidine hydrochloride (see Materials and methods), reprobed with the same DNA samples, and autoradiographed a second time. Note that the procedure selectively enhances interaction of the C/EBP probe with protein deposited by the L 20 bacteriophage plaques (image $1 B$ ). The filters were cycled through a second denaturation/renaturation step, which effectively removed all radioactive DNA from the filters (images $1 C$ and $2 C$ ). Finally, the filter from plate 1 , which had been exposed to the C/EBP DNA probe in the initial two rounds of binding, was exposed to the salmon sperm probe. Likewise, the filter from plate 2, which had been exposed to the salmon sperm probe in the initial two rounds, was exposed to the synthetic C/EBP probe. Images $1 D$ and $2 D$ demonstrate that binding specificity of the C/EBP probe to proteins deposited by the L 20 plaques is retained even after two cycles of denaturation/renaturation. teraction between the catenated C/EBP DNA probe and protein deposited by the $\mathrm{L} 20$ bacteriophage. The selectivity of this interaction was demonstrated by the failure of the salmon sperm DNA probe to interact with protein expressed by L20, as well as by the failure of the cate-

PLATE 1 PLATE 2

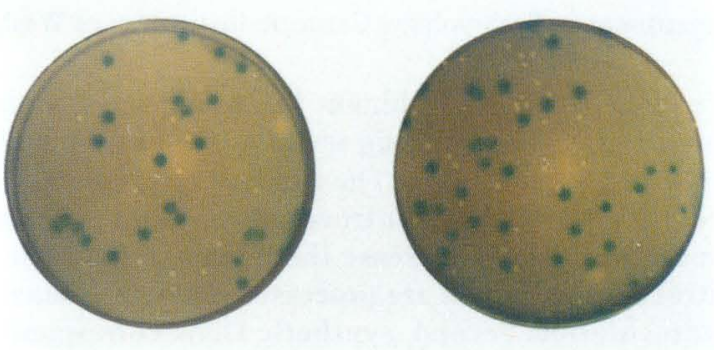

A
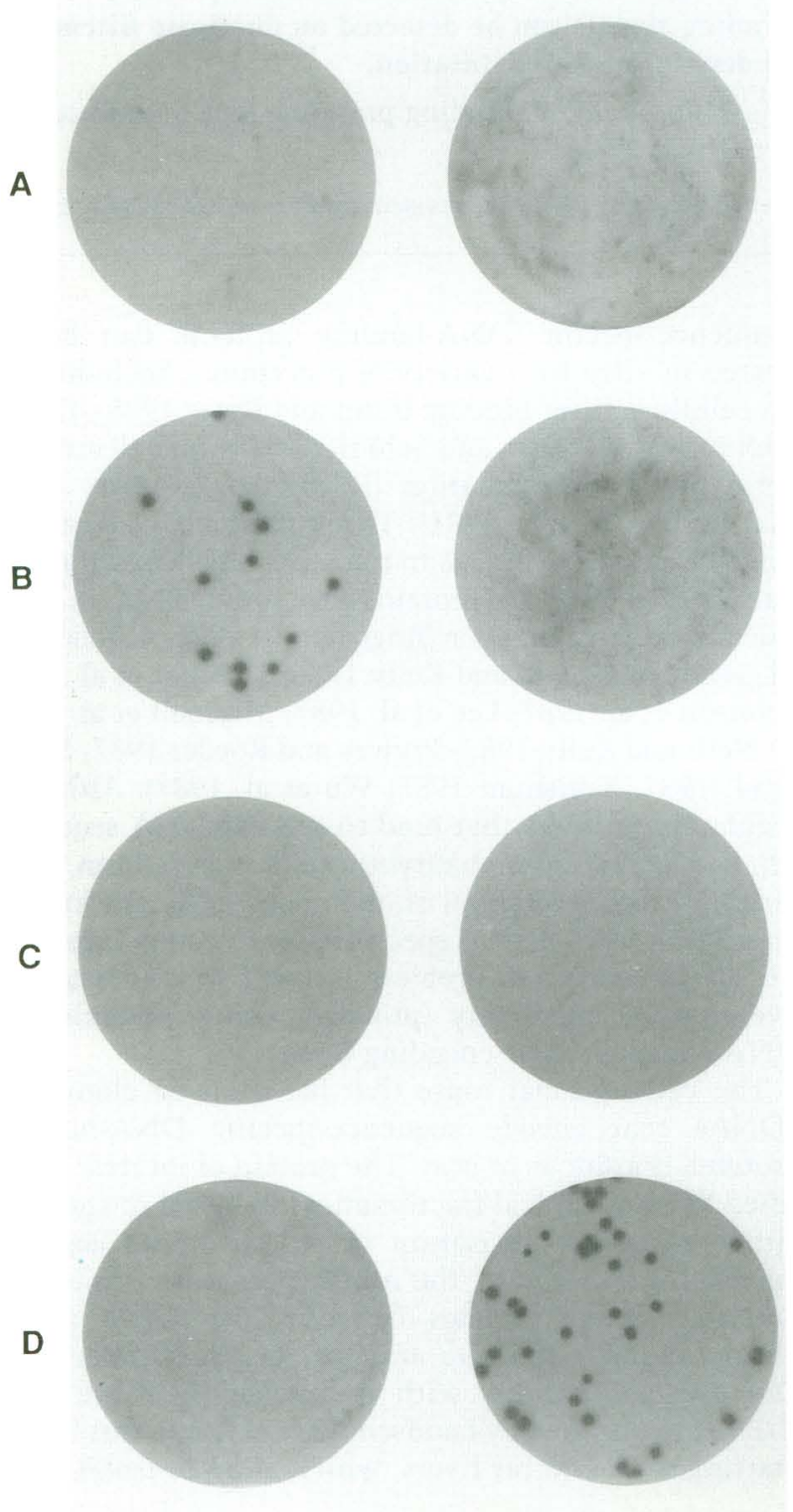
nated C/EBP DNA to interact with protein synthesized by $\lambda$ gtll.

After obtaining an autoradiographic image, each filter was subjected to a second cycle of denaturation/renaturation and again exposed to X-ray film overnight. As expected, this process removed the synthetic DNA probe from L20-derived protein, rendering the filters clean of radioactive DNA. The erased filters were then switched and challenged in binding assays with the opposite probes. The two autoradiographic images at the bottom of Figure 1D show that the synthetic DNA bound selectively and appreciably with L20-derived protein after two rounds of denaturation/renaturation.

Having obtained evidence of selective in situ interaction between synthetic C/EBP-binding site and L20-derived protein, we set out to test the importance of using a catenated probe. Parallel filters were lifted from plates that contained $\sim 100$ L20 plaques. Each filter was exposed to the sequential denaturation/renaturation regimen described in Figure 1. One of the filters was probed with monomer-length C/EBP synthetic DNA, and the other was probed with catenated DNA labeled with ${ }^{32} \mathrm{P}$ to roughly the same specific activity (see Materials and methods). Figure 2 shows that the L20-derived fusion protein bound far more efficiently to the catenated DNA probe.

Observations presented thus far suggested that our procedures might be suitable for the selection of rare clones out of a complex $\lambda$ gt 11 library. To test this possibility, we reconstituted a rat kidney cDNA library with a known number of L20 bacteriophage and screened $10-\mathrm{cm}$ petri plates containing 2000 phage per plate. Two filter lifts were retrieved from each plate. The first filter was placed on the bacterial lawn $4 \mathrm{hr}$ post-infection and removed $6 \mathrm{hr}$ later. A second filter was then applied to each plate and incubated for an additional $2 \mathrm{hr}$. The filters were cycled through $6 \mathrm{~m}$ guanidine hydrochloride and probed with catenated C/EBP-binding site. Figure 3 shows that these procedures are adequate to identify the L20 bacteriophage that were spiked into the library. Importantly, the L20 bacteriophage could be detected on both the original and duplicate nitrocellulose filters.

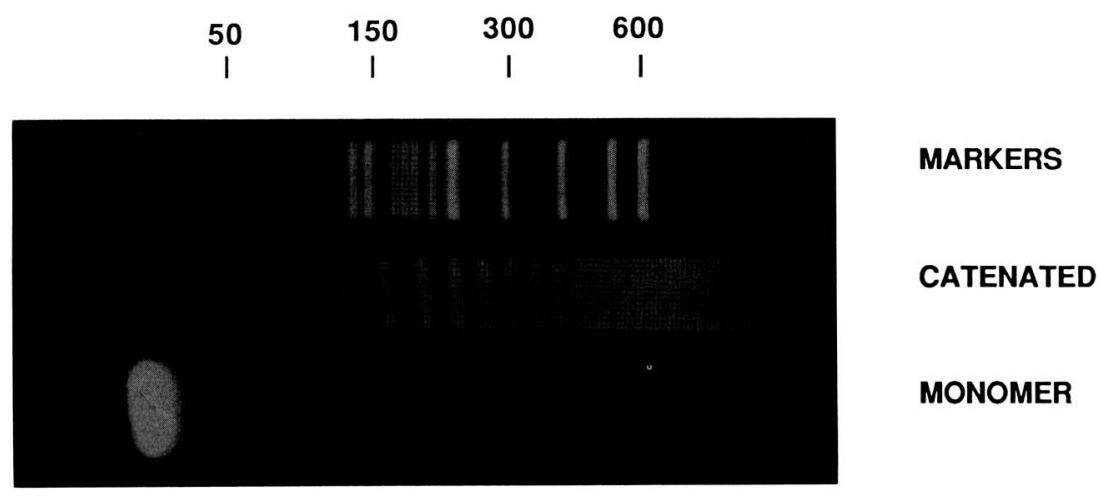

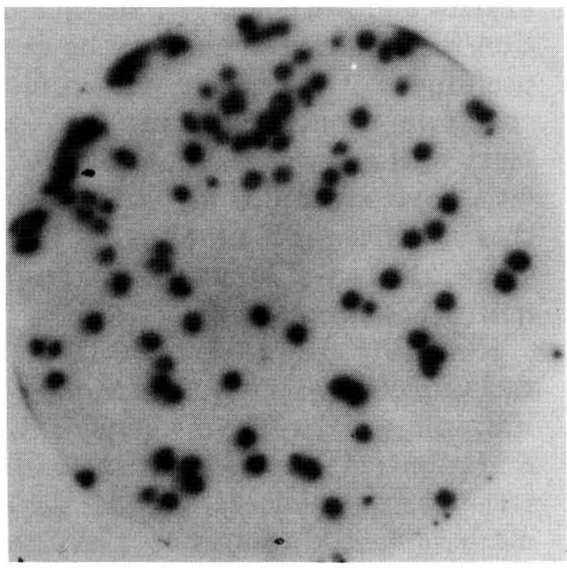

CATENATED

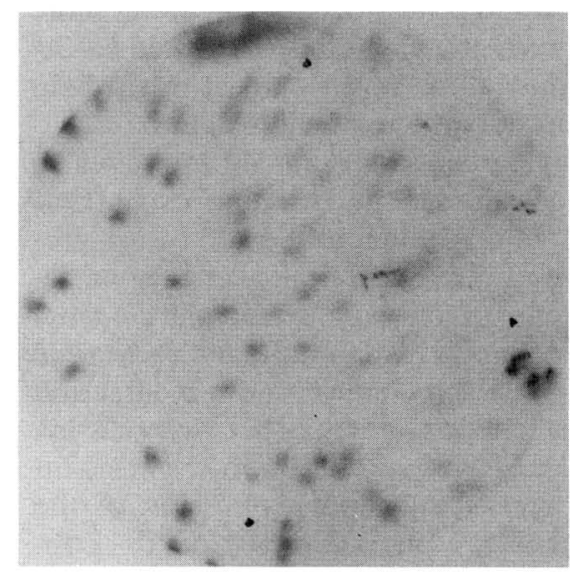

MONOMER

Figure 2. Influence of probe catenation on in situ detection of sequence-specific DNA binding. Two petri plates were inoculated with bacterial cells that had been infected with $\sim 100$ plaque-forming units (pfu) of bacteriophage L20. Filter replicas were prepared by published procedures (Young and Davis 1983) and processed by denaturation/renaturation through guanidine hydrochloride (see Materials and methods). One filter was probed with catenated C/EBP-binding site; the other was probed with monomer-length-binding site. The autoradiographic images produced by the two filters are shown at the bottom. The top shows the ethidium-bromide-stained images of monomer and catenated C/EBP-binding site probes following sizing on a polyacrylamide electrophoresis gel. Molecular weight markers are MspI digestion products of pBR322 plasmid DNA. 
Primary Lift

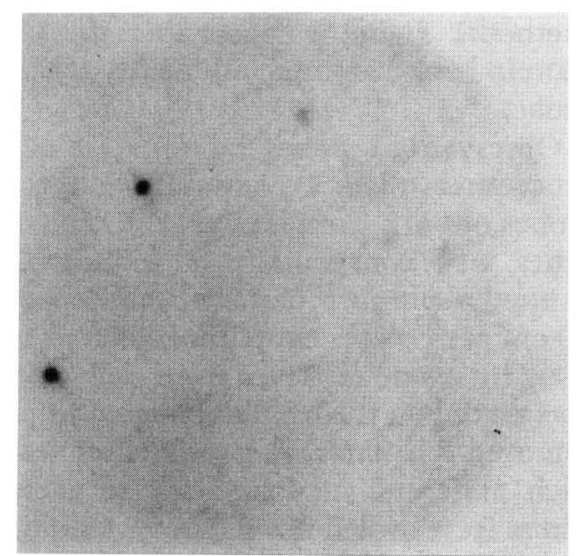

Secondary Lift

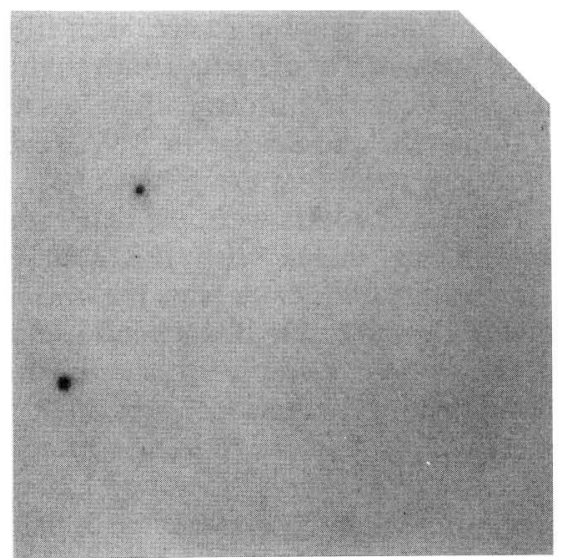

Figure 3. In situ aetection of the L2U bacteriophage in a background of 2000 bacteriophage plaques derived trom a rat kidney cDNA library. Bacterial cells were infected with 2000 pfu of a rat kidney cDNA library cloned in bacteriophage $\lambda$ gt $l 1$ and plated onto a single $10-\mathrm{cm}$ petri plate. The bacteriophage recombinant carrying a C/EBP cDNA insert, L20, was spiked into the library at a ratio of $1: 1000$ relative to the rat kidney cDNAs. Two nitrocellulose filter lifts were retrieved, cycled through guanidine hydrochloride, and probed with catenated C/EBP-binding site. The first filter (primary lift) was left on the the plate for $6 \mathrm{hr}$ and was then replaced by a second filter (secondary lift), which was left on the plate for $2 \mathrm{hr}$. After exposure to the C/EBP probe and washing, the filters were exposed to $\mathrm{X}$-ray film overnight, generating the autoradiographic images shown.

\section{Discussion}

We have described two procedures that may be helpful in facilitating the direct retrieval of cDNAs that encode sequence-specific DNA-binding proteins. Although the efficacy of these procedures has only been tested on the product of the bacteriophage that encodes C/EBP, there are several reasons to suspect that these modifications may be of general utility. The use of a catenated probe consisting of a high density of protein-binding sites may allow a single DNA molecule to be tethered at more than one site to its cognate, bacterially produced DNAbinding protein. If this is indeed the case, it might help alleviate the problem of rapid probe dissociation.

It is less clear why detection signals are improved so markedly by the denaturation/renaturation cycle. One possible explanation is that much of the $\mathrm{L} 20$ fusion protein produced in the infected bacterial cells may be deposited in an insoluble, precipitated form that prevents access to the DNA probe. Guanidine hydrochloride might 'melt' the insoluble precipitate, and some fraction of the protein might renature binding specificity during the graded removal of the denaturant. In light of this interpretation, we note that bacterial expression of the adenovirus E1A gene (Ferguson et al. 1984) and the Drosophila engrailed gene (Desplan et al. 1985) leads to the expression of insoluble proteins that require exposure to chaotropic agents for solubilization. Alternatively, appropriate folding or multimerization of a foreign protein may not occur in $E$. coli, and the denaturation/renaturation process may help to overcome this problem. Finally, we point out that the beneficial action of a denaturation/renaturation cycle on the activity of a nitrocellulose-adsorbed protein has been documented convincingly in a previous study (Celenza and Carlson 1986).

It is important to point out that $\mathrm{C} / \mathrm{EBP}$ is known to be capable of renaturing sequence-specific DNA-binding activity following denaturation in $6 \mathrm{M}$ guanidine hydrochloride (Johnson et al. 1987). Because renaturability is a property common to many eukaryotic proteins that bind DNA in a sequence-specific manner (Briggs et al. 1986; Chodosh et al. 1986; Fletcher et al. 1987; Lee et al. 1987; Prywes and Roeder 1987), we predict that the denaturation/renaturation cycle may be of general utility. The usefulness of our techniques in cloning genes that encode rare, sequence-specific DNA-binding proteins has been verified in at least one case. A. Keller and T. Maniatis have succeeded in retrieving a recombinant clone that specifies the synthesis of a fusion protein that binds specifically to a domain of the human $\beta$-interferon promoter (pers. comm.).

However expeditious the direct DNA ligand screening technique may appear, it is attended by certain obvious limitations. First, the resilience of C/EBP protein to denaturation/renaturation may make this system uncharacteristically amenable to the DNA ligand screening method. In addition, it is likely that some eukaryotic DNA-binding proteins will simply not be expressible in an active configuration in bacterial cells. For example, certain sequence-specific regulatory factors require two different polypeptide subunits to generate sequence-specific binding activity (Goutte and Johnson 1988; L.A. Chodosh et al., S. Hahn and L. Guarente, both in press). cDNAs encoding this class of factors would, of course, be impossible to isolate by the scheme described herein. Authentic DNA-binding activity of other proteins may 
require specific post-translational modifications that are not provided in E. coli. Despite these caveats, we are optimistic that in some cases, the DNA ligand binding screen that we describe will expedite the cloning of genes encoding eukaryotic DNA-binding proteins.

\section{Materials and methods}

E. coli strains and recombinant bacteriophage

The standard strain for lytic growth of bacteriophage igtll, Y1090, was used throughout the described procedure (Young and Davis 1983|. A recombinant derivative of bacteriophage $\lambda$ gt 11, termed L20 was used to test for in situ protein-DNA interaction on nitrocellulose filters. The cDNA insert of L20 (Landschulz et al., this issue) encodes the DNA-binding domain of the enhancer binding protein termed C/EBP (Johnson et al. $1987)$ and is fused in frame with the $\beta$-galactosidase gene of $\lambda g t 11$. Bacteriophage $\lambda$ gt 11 was used as a negative control for nonspecific binding of radioactive DNA to proteins deposited by bacteriophage plaques. $\mathrm{L} 20$ plaques were distinguished from $\lambda$ gtll plaques by the standard X-gal color assay specific for $\beta$ galactosidase (Miller 1972). The reconstruction experiment described in Figure 3 utilized the L20 recombinant mixed at a $1: 1000$ ratio with an unamplified $\lambda$ gt 11 library that was prepared using rat kidney cDNA (W. Landschulz, unpubl.).

\section{DNA probes}

The C/EBP probe was generated starting with the two complementary, synthetic oligonucleotides shown below:

\section{5'-AATTCAATTGGGCAATCAGG - 3 ' $3^{\prime}$ - GTTAACCCGTTAGTCCT TAA-5'}

Five micrograms of each oligonucleotide were phosphorylated with unlabeled rATP and polynucleotide kinase in $50-\mu 1$ reactions using conditions specified by the supplier (New England Biolabs). The two oligonucleotides were then mixed (still in the polynucleotide kinase reaction buffer) and heated for successive 15 -min intervals at $65,37,24$, and $4^{\circ} \mathrm{C}$. The reaction was then supplemented with DNA ligase (10 units, New England Biolabs) and incubated for $12 \mathrm{hr}$ at $15^{\circ} \mathrm{C}$. Catenated DNA, which attained a mean length of $\sim 200 \mathrm{bp}$ (see Fig. 2), was purified from contaminating proteins by organic extraction and concentrated by ethanol precipitation. Radiolabeled probe was prepared by 'nick-translating' $500 \mathrm{ng}$ of the catenated oligonucleotide using $[\alpha-32 \mathrm{P}] \mathrm{dATP}$ and $\left[\alpha^{-32} \mathrm{P}\right] \mathrm{dCTP}$ (Maniatis et al. 1982). Typical labeling reactions yielded probe with a sp. act. of $10^{8} \mathrm{cpm} / \mu \mathrm{g}$.

Salmon sperm DNA, used as a nonspecific filter-binding probe, was sheared by sonication to a mean length of $400 \mathrm{bp}$. Salmon sperm DNA was also labeled by nick-translation, yielding specific activities comparable to that introduced into the catenated oligonucleotide probe.

The influence of probe catenation was examined by comparing the binding properties of monomer-length and catenated oligonucleotides. The same molar quantity of monomer and catenated DNA was end-labeled with $\left[\gamma^{-32} \mathrm{P}\right] \mathrm{ATP}(3000 \mathrm{Ci} /$ mmole, Amersham) and polynucleotide kinase (New England Biolabs). Monomer-length probe attained a sp. act. of $1.2 \times 10^{6}$ $\mathrm{cpm} / \mathrm{pmole}$. Catenated probe, assuming a mean length of 200 $\mathrm{bp}$, attained a sp. act. of $2.0 \times 10^{6} \mathrm{cpm} / \mathrm{pmole}$.

\section{Preparation of nitrocellulose filters}

Bacteriophage infection and plating of infected $E$. coli onto petri plates was carried out according to the methods of Young and Davis (1983). Culture plates were grown for between 3 and $4 \mathrm{hr}$ at $42^{\circ} \mathrm{C}$, overlayed with IPTG-impregnated nitrocellulose filters (Schleicher and Schuell), and incubated for an additional $6 \mathrm{hr}$ at $37^{\circ} \mathrm{C}$. Duplicate filters were prepared by overlaying a second IPTG-impregnated filter onto the plate after removal of the original filter. The second filter was left in place for $2 \mathrm{hr}$ at $37^{\circ} \mathrm{C}$.

After removal from culture plates, nitrocellulose filters were allowed to air-dry for $15 \mathrm{~min}$ at room temperature. All subsequent procedures were carried out at $4^{\circ} \mathrm{C}$. After drying, filters were submerged in $250 \mathrm{ml}$ of binding buffer $[25 \mathrm{mM} \mathrm{NaCl}, 5$ $\mathrm{mM} \mathrm{MgCl}_{2}, 0.5 \mathrm{~mm}$ dithiothreitol (DTT), and $25 \mathrm{~mm}$ HEPES [pH 7.9)] supplemented with $6 \mathrm{M}$ guanidine hydrochloride. After gentle shaking in a glass baking dish for $10 \mathrm{~min}$, the solution was decanted and replaced with $250 \mathrm{ml}$ of the same buffer. This second wash was left on the filters for $10 \mathrm{~min}$, decanted into a $500 \mathrm{ml}$ graduated cylinder, and supplemented with an equal volume of binding buffer without guanidine hydrochloride. Then, $250 \mathrm{ml}$ of the $100 \%$ dilution was replaced into the baking dish and allowed to mix with the filters for $5 \mathrm{~min}$. This $100 \%$ dilution step was repeated four times, and the final step was followed by two $250-\mathrm{ml}$ washes with unsupplemented binding buffer. The filters were then transferred to a fresh baking dish containing $250 \mathrm{ml}$ of binding buffer supplemented with $5 \%$ Carnation nonfat dry milk (Miskimins et al. 1985). After gentle shaking for $30 \mathrm{~min}$, the solution was decanted and replaced with $250 \mathrm{ml}$ of binding buffer supplemented with $0.25 \%$ dry milk.

Exposure of filters to DNA probe was carried out in $110-\mathrm{mm}$ glass crystallization dishes using $100 \mathrm{ml}$ of binding buffer supplemented with $0.25 \%$ dry milk and $10^{6} \mathrm{cpm} / \mathrm{ml}$ of radiolabeled probe DNA. Binding reactions used up to 15 filters per crystallization dish and were shaken gently for $2 \mathrm{hr}$. After exposure to probe DNA, filters were washed over a $15-\mathrm{min}$ period with three $300-\mathrm{ml}$ changes of binding buffer plus $0.25 \%$ milk. Filters were blotted briefly on $3 \mathrm{MM}$ paper, sandwiched between layers of Saran wrap on a stiff paper support and exposed to Kodak $\mathrm{X}$-Omat AR film overnight at $-70^{\circ} \mathrm{C}$ with the aid of a Dupont Lightning-Plus intensifying screen.

\section{Acknowledgments}

We thank Bob Kingsbury for excellent technical assistance, Connie lewell for extensive help with the preparation of figures, and Christine Pratt for clerical assistance in preparation of the manuscript. C.R.V. was supported by a postdoctoral fellowship award from the American Cancer Society; K.L.L. by a postdoctoral fellowship award from the Leukemia Society; and P.F.J. by postdoctoral fellowship awards from the Damon Runyon/Walter Winchell Cancer Fund and the Carnegie Corporation; W.H.L. by a predoctoral award from the Life and Health Insurance Medical Research Fund; and S.L.M. by a Faculty Research Award from the American Cancer Society. This work was otherwise funded by a grant awarded to S.L.M. from the National Institutes of Health.

\section{References}

Briggs, M.R., J.T. Kadonaga, S.P. Bell, and R. Tjian. 1986. Purification and biochemical characterization of the promoterspecific transcription factor, Spl. Science 234: 47-52.

Celezna, J.L. and M. Carlson. 1986. A yeast gene that is essen- 
tial for release from glucose repression encodes a protein $\mathrm{ki}$ nase. Science 233: 1175-1180.

Chodosh, L.A., R.W. Carthew, and P.A. Sharp. 1986. A single polypeptide possesses the binding and transcription activities of the adenovirus major late transcription factor. Mol. Cell. Biol. 6: 4723-4733.

Chodosh, L.A., A.L. Baldwin, R.W. Carthew, and P.A. Sharp. 1988. Human CCAAT-binding proteins have heterologous subunits. Cell 53: 11-24.

Desplan, C., J. Theis, and P.H. O'Farrell. 1985. The Drosophila developmental gene, engrailed, encodes a sequence-specific DNA binding activity. Nature 318: 630-635.

Ferguson, B., N. Jones, J. Richter, and M. Rosenberg. 1984. Adenovirus Ela gene product expressed at high levels in Escherichia coli is functional. Science 224: 1343-1346.

Fletcher, C., N. Heintz, and R.G. Roeder. 1987. Purification and characterization of OTF-1, a transcription factor regulating cell cycle expression of a human histone gene. Cell 51: $773-781$.

Fried, M. and D.M. Crothers. 1981. Equilibrium and kinetics of lac repressor-operator interactions by polyacrylamide gel electrophoresis. Nucleic Acids Res. 9: 6505-6525.

Galas, D.J. and A. Schmitz. 1978. DNase footprinting: A simple method for detection of protein-DNA binding specificity. Nucleic Acids Res. 5: 3157-3171.

Garner, M.M. and A. Revzin. 1981. A gel electrophoresis method for quantifying binding of proteins to specific DNA regions: Applications to components of the Escherichia coli lactose operon regulatory system. Nucleic Acids Res. 9: 3047-3060.

Goutte, C. and A.D. Johnson. 1988. al protein alters the DNA binding specificity of $\alpha 2$ repressor. Cell 52: 875-882.

Johnson, P.F., W.H. Landschulz, B.J. Graves, and S.L. McKnight. 1987. Identification of a rat liver nuclear protein that binds to the enhancer core element of three animal viruses. Genes Dev. 1: 133-146.

Lee, W., P. Mitchell, and R. Tjian. 1987. Purified transcription factor AP-1 interacts with TPA-inducible enhancer elements. Cell 49: 741-752.

Lin, S.-Y. and A.D. Riggs. 1975. The general affinity of lac repressor for $E$. coli DNA: Implication for gene regulation in prokaryotes and eukaryotes. Cell 4: 107-111.

Maniatis, T., E.F. Fritsch, and J. Sambrook. 1982. Molecular cloning: A laboratory manual. Cold Spring Harbor Laboratory, Cold Spring Harbor, New York.

Miller, J.H. 1972. Experiments in molecular genetics. Cold Spring Harbor Laboratory, Cold Spring Harbor, New York.

Miskimins, W.K., M.P. Roberts, A. McClelland, and F.H. Ruddle. 1985. Use of a protein-blotting procedure and a specific DNA probe to identify nuclear proteins that recognize the promoter region of the transferring receptor gene. Proc. Natl. Acad. Sci. 82: 6741-6744.

Mitchell, P.J., C. Wang, and R. Tjian. 1987. Positive and negative regulation of transcription in vitro: Enhancer-binding protein AP-2 is inhibited by SV40 T antigen. Cell 50: 847861.

O'Neill, E.A. and T.J. Kelly. 1987. Purification and characterization of nuclear factor III (origin recognition protein c), a sequence-specific DNA binding protein required for efficient initiation of adenovirus DNA replication. I. Biol. Chem. 263: 931-937.

Prywes, R. and R.G. Roeder. 1987. Purification of the c-fos enhancer-binding protein. Mol. Cell. Biol. 7: 3482-3489.

Rosenfeld, P.J. and T.J. Kelly. 1986. Purification of nuclear factor I by DNA recognition site affinity chromatography. J. Biol. Chem. 261: 1398-1408.
Singh, H., J.H. LeBowitz, A.S. Baldwin, and P.A. Sharp. 1988. Molecular cloning of an enhancer binding protein: Isolation by screening of an expression library with a recognition site DNA. Cell 52: 415-423.

Sturm, R., T. Baumruker, B.R. Franza, and W. Herr. 1987. A $100-\mathrm{kD}$ HeLa cell octamer binding protein (OBP100) interacts differently with two separate octamer-related sequences within the SV40 enhancer. Genes Dev. 1: 11471160.

Treisman, R. 1987. Identification and purification of a polypeptide that binds to the c-fos serum response element. $E M B O$ J. 6: $2711-2717$.

Wu, C., S. Wilson, B. Walker, I. Dawid, T. Paisley, V. Zimarino, and U. Hitoshi. 1987. Purification and properties of Drosophila heat shock activator protein. Science 238: 1247-1253.

Young, R.A. and R.W. Davis. 1983. Efficient isolation of genes by using antibody probes. Proc. Natl. Acad. Sci. 80: 11941198. 


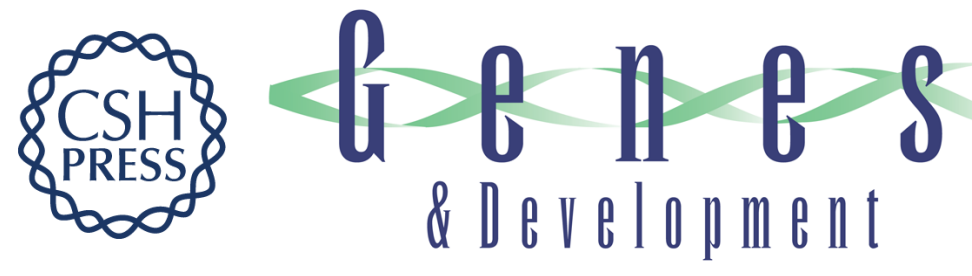

\section{In situ detection of sequence-specific DNA binding activity specified by a recombinant bacteriophage.}

C R Vinson, K L LaMarco, P F Johnson, et al.

Genes Dev. 1988, 2:

Access the most recent version at doi:10.1101/gad.2.7.801

References This article cites 24 articles, 11 of which can be accessed free at:

http://genesdev.cshlp.org/content/2/7/801.full.html\#ref-list-1

License

Email Alerting Receive free email alerts when new articles cite this article - sign up in the box at the top Service right corner of the article or click here.

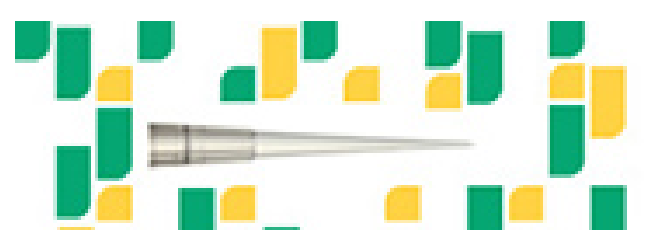

Focused on your science. 